Overend, W. G., Stacey, M., WebB, M. \& Ungar, J. (1951). J. gen. Microbiol. 5, 268-275.

\title{
The Isolation of Deoxyribonucleic Acid from Virulent and Avirulent Strains of Haemophilus pertussis
}

\author{
BY W. G. OVEREND, M. S'TACEY, M. WEBB \\ The Chemistry Department, The University, Edgbaston, Birmingham 15 \\ AND J. UNGAR \\ Glaxo Laboratories Ltd., Greenford, Middlesex
}

\begin{abstract}
SUMMARY : Haemophilus pertussis cells contain a relatively large amount of deoxyribonucleic acid which may be extracted from the organisms with $2 \%$ sodium cholate.

A method is described for the isolation of deoxyribonucleic acid from the mechanically disintegrated organisms, which yields an apparently undegraded preparation free from ribonucleic acid and protein, but containing a polysaccharide component, probably in combination with the nucleic acid. This finding gives further evidence of the differences in biological properties of virulent and avirulent strains such as agglutinability by type-specific serum, precipitability by aluminium phosphate, and solubility in bile and sodium hydroxide.
\end{abstract}

Although the nucleic acid content of bacteria is relatively high compared with that of animal and higher plant tissues (Boivin, Tulasne \& Vendrely, 1947; Belozerski, 1947), the isolation of bacterial nucleic acids, and particularly deoxyribonucleic acids, has been restricted by the difficulties of cultivation of the organisms in sufficient quantity and of disrupting the cells. In consequence, much of the earlier work on the deoxyribonucleic acids of bacteria (cf. reviews by Levene \& Bass, 1931; Stacey, 1947) was concerned with the properties of small quantities of impure and considerably degraded material, often obtained by the use of strong alkalis. However, with the introduction in recent years of methods for the mechanical disintegration of micro-organisms, highly polymerized preparations of deoxyribonucleic acid have been isolated from yeast (Chargaff \& Zamenhof, 1947, 1948) and an avian strain of Mycobacterium tuberculosis (Chargaff \& Saidel, 1949) by mild procedures analogous to those developed initially by Mirsky \& Pollister (1942) for the preparation of deoxyribonucleic acids from animal tissues.

The demonstration of the essential role of deoxyribonucleic acids in the transformation of pneumococcus types (Avery, McLeod \& McCarty, 1944), and in the mutation of colon bacilli (Boivin, 1947), serves to emphasize the importance of a study of the properties of deoxyribonucleic acids isolated from micro-organisms under mild conditions. In initial experiments along these lines we attempted to isolate deoxyribonucleic acid from suspensions of Micrococcus lysodeikticus lysed with lysozyme, since Meyer \& Hahnel (1946) observed that the high viscosity of such lysates was abolished by deoxyribonuclease. However, in our hands the yield of deoxyribonucleic acid from this source was negligible.

Recently Ungar \& Muggleton (1949) showed that in addition to the wellknown phase-specificity of Haemophilus pertussis, there are physico-chemical methods which differentiate between certain strains of $\boldsymbol{H}$. pertussis. Virulent 
strains of $\boldsymbol{H}$. pertussis, agglutinated only by specific phase I antiserum, are precipitated by suspensions of aluminium phosphate and are dissolved by $10 \%$ sodium desoxycholate and sodium hydroxide solutions; in contrast, avirulent strains of $\boldsymbol{H}$. pertussis are not affected by these reagents. Further; virulent strains form capsules in $24 \mathrm{hr}$. on Bordet-Gengou medium and require starch for their growth in fluid semi-defined medium. (Ungar, James, Pegler, Muggleton \& Tomich, 1950). It has also been observed that the material removed from $H$. pertussis by $2 \%$ sodium cholate solution at $60^{\circ}$ contains a high percentage of deoxyribonucleic acid (Webb, 1949). Together these observations seemed to indicate that the differences in the serological and physico-chemical behaviour of the two types of $H$. pertussis were based on differences in chemical composition. Using relatively large quantities of freezedried virulent and avirulent $H$. pertussis cultures, we have confirmed and extended these findings and have devised a method for the isolation of deoxyribonucleic acid from these sources in a comparatively undegraded form, free from all but traces of ribonucleic acid and protein.

In the present paper we describe the method of isolating the deoxyribonucleic acids. The main analytical data and physical properties of the preparations will be reported subsequently.

\section{EXPERIMENTAL}

\section{Cultivation of the organisms}

The virulent (83E) and avirulent (154E) strains of $H$. pertussis were grown in 1 l. screw-capped medicine bottles containing $250 \mathrm{ml}$. of semi-defined fluid medium consisting of salts, hydrolysed casein, soluble starch and yeast dialysate (Cohen $\&$ Wheeler, 1946). After 12 days at $37^{\circ}$, the organisms were collected by centrifugation, washed with saline and dried in the frozen state. The deoxyribonucleic acid content was c. $4 \%$ (Table 1 ).

Although a prolonged period of growth was required to obtain the maximum

\section{Table 1. Phosphoprotein, deoxyribonucleic and ribonucleic acid content} of the residual culture medium and of Haemophilus pertussis cells

Determinations by the method of Schmidt \& Thannhauser (1945). Results expressed as $\mathrm{mg}$. $\mathbf{P} / 50 \mathrm{mg}$. dry cells or evaporated culture medium.

(mg. P/50 mg. dry material)

\begin{tabular}{|c|c|c|c|}
\hline Material & $\begin{array}{l}\text { Deoxyribonucleic } \\
\text { acid }\end{array}$ & $\begin{array}{l}\text { Ribonucleic } \\
\text { acid }\end{array}$ & Phosphoprotein \\
\hline $\begin{array}{l}\text { Virulent }(83 \mathrm{E}) \boldsymbol{H} \cdot \text { pertussis } \\
\text { cells }\end{array}$ & $0 \cdot 214$ & 0.412 & Nil \\
\hline $\begin{array}{l}\text { Residual culture medium } \\
\text { after growth of virulent } \\
(83 \mathrm{E}) \text { cells }\end{array}$ & 0.005 & $0 \cdot 506$ & 0.094 \\
\hline $\begin{array}{l}\text { Avirulent (154E) H. per- } \\
\text { tussis cells }\end{array}$ & $0 \cdot 190$ & $0 \cdot 392$ & $0 \cdot 005$ \\
\hline $\begin{array}{l}\text { Residual culture medium } \\
\text { after growth of avirulent } \\
(154 \mathrm{E}) \text { cells }\end{array}$ & 0.002 & 0.427 & 0.093 \\
\hline
\end{tabular}


yield of organisms, no evidence of autolysis was observed in stained smears prepared from the cells at the end of the growth period, and chemical analysis of the residual culture medium after evaporation failed to show any significant amount of deoxyribonucleic acid (Table 1).

\section{Extraction of Haemophilus pertussis cells with $2 \%$ sodium cholate solution at $60^{\circ}$}

The virulent (83E, 1.0 g.) and avirulent (154 E, 0.85 g.) $H$. pertussis cells were extracted with $2 \%(\mathrm{w} / \mathrm{v})$ sodium cholate solution $\left(100 \mathrm{ml}\right.$.) at $60^{\circ}$, according to the method described by Henry \& Stacey $(1943,1946)$. After $48 \mathrm{hr}$. the suspensions were centrifuged, the supernatants decanted (the extract of the avirulent organisms was extremely viscous and was obtained clear only after $4 \mathrm{hr}$. at 4500 r.p.m.) and the cell debris, in each case, washed with water and ethanol (twice) and dried with ethanol and ether. Absolute ethanol (4 vol.) was added to each of the aqueous sodium cholate extracts and the resulting precipitates (long fibres in the case of the extract from the avirulent organisms) were collected after $18 \mathrm{hr}$. by centrifugation, dehydrated with ethanol and dried with ethanol and ether. In this way 0.14 and $0.22 \mathrm{~g}$. of material, which gave the usual qualitative tests for proteins and nucleic acids, were obtained from the extracts of the virulent and avirulent organisms respectively.

Table 2. The distribution of ribonucleic and deoxyribonucleic acid in the nucleic acid fraction removed from Haemophilus pertussis cells by extraction with $2 \%$ sodium cholate solution at $60^{\circ}$, and in the cell debris remaining after extraction

Determinations by the method of Schmidt \& Thannhauser (1945). Results expressed as $\mathrm{mg} . \mathbf{P} / \mathrm{mg}$. dry nucleic acid fraction or cell debris.

Material
Nucleic acid fraction from sodium cholate
extract of virulent $\boldsymbol{H}$. pertussis $(83 \mathrm{E})(\mathrm{re}-$
ducing value after acid hydrolysis $=27 \%)$
Virulent $\boldsymbol{H}$. pertussis (83E) cell residue after
sodium cholate extraction
Nucleic acid fraction from sodium cholate
extract of avirulent $\boldsymbol{H}$. pertussis $(154 \mathrm{E})$ (re-
ducing value after acid hydrolysis $=7 \%$ )
Avirulent $\boldsymbol{H}$. pertussis (154 E) cell residue
after sodium cholate extraction

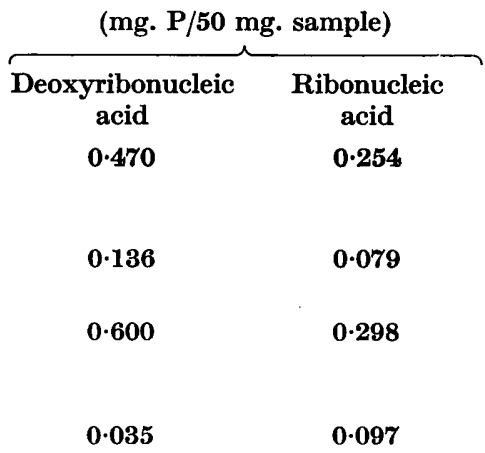

The analysis of these fractions by the Schmidt \& Thannhauser (1945) procedure gave the results recorded in Table 2 , which indicate that the extraction with sodium cholate removed most of the deoxyribonucleic acid of the cells. The material removed from the virulent organism $(83 \mathrm{E})$ under these conditions had a reducing value, after acid hydrolysis, equivalent to $27 \%$ reducing sugar (as glucose), whereas the corresponding fraction from the avirulent organism yielded $7 \%$ reducing sugar on hydrolysis (Table 2). Since this latter value 
must include the increase in reducing value due to the acid hydrolysis of the purine nucleotides, it is apparent that the extract from the virulent $H$. pertussis cells contained a polysaccharide component as well as protein and nucleic acids. It appears probable that the presence of this (specific) polysaccharide, mainly among the components of the sodium cholate extract of the virulent $\boldsymbol{H}$. pertussis cells, is responsible, in some way, for the marked differences between the physical properties of the extracts from the virulent and avirulent organisms and for the differences in the ease of extraction of the cell components.

Isolation of deoxyribonucleic acid from Haemophilus pertussis

Although the procedure outlined above removed much of the deoxyribonucleic acid from the $H$. pertussis cells (Table 2 ), the alkalinity ( $\mathrm{pH} 8$ ) of the sodium cholate solution and the temperature at which the extraction was carried out probably caused some degradation of the nucleic acid molecule. In the following experiments, designed to overcome these difficulties, the dry bacteria were ground with $1.0 \mathrm{M}$ sodium chloride solution to give a thick suspension, which was then shaken with the same volume of glass beads (ballotini) in a Mickle shaker (H. Mickle, Hampton, Middlesex) to disintegrate the organisms. Although the deoxyribonucleoprotein of $\boldsymbol{H}$. pertussis was soluble in water and 0.14M sodium chloride, the extraction was carried out with $1.0 \mathrm{M}$ sodium chloride, since microscopic examination showed that more complete disintegration of the cells $(60-70 \%)$ occurred under these conditions and resulted in higher yields of the nucleoprotein. Thus the yields of nucleoprotein obtained from $0.45 \mathrm{~g}$. $83 \mathrm{E}$ cells, by the procedure described below, were respectively 75 and $35 \mathrm{mg}$. when the cells were disintegrated in $1 \cdot 0$ and $0.14 \mathrm{M}$ sodium chloride.

Since it was considered that the polysaccharide previously encountered among the components of the sodium cholate extract of the virulent organism was located at the cell surface, attempts were made to remove this material, first by washing the intact organism with $0 \cdot 14 \mathrm{M}$.sodium chloride according to the method of Pittman (1931) for the removal of the soluble specific substance from $\boldsymbol{H}$. influenzae. However, this procedure was abandoned, since the addition of ethanol to saline washings of virulent $H$. pertussis cells resulted in the immediate precipitation of long fibres which were easily removed from the granular precipitate, which separated more slowly. This fibrous precipitate gave a positive Dische (1930) reaction, and analysis by the Schmidt \& Thannhauser (1945) method showed that it contained 6-7\% deoxyribonucleic acid. Since previous observations indicated that little or no autolysis occurred during the cultivation of the organisms, the presence of deoxyribonucleic acid in the saline washings of $\boldsymbol{H}$. pertussis cells may be of some significance in connexion with the location of this nucleic acid within the bacterial cell (cf. Boivin, 1948).

\section{Preparation of crude nucleoprotein}

One typical preparation will be described. The $H$. pertussis cells (10 g.) were dispersed in $1.0 \mathrm{M}$ sodium chloride $(200 \mathrm{ml}$.) by vigorous agitation in an 'AtoMix' homogenizer no. 800 (Measuring and Scientific Equipment Ltd., 14-28 
Spencer Street, London S.W. 1). The resulting homogeneous suspension was allowed to stand at $0^{\circ}$ overnight and then centrifuged. The supernatant $\left(S_{1}\right)$ was decanted and stored at $0^{\circ}$. The residual cell suspension was diluted with 1.0 M sodium chloride $(15 \mathrm{ml}$.), mixed with ballotini and shaken in the Mickle shaker. After $30 \mathrm{~min} .\left(3 \times 10 \mathrm{~min}\right.$.) the suspension was diluted with $S_{1}(150 \mathrm{ml}$.), thoroughly mixed and centrifuged after $18 \mathrm{hr}$. at $0^{\circ}$. The supernatant $\left(S_{2}\right)$ was decanted and the residual cells and debris were re-treated in the Mickle shaker

Table 3. Approximate nucleic acid content of fractions obtained during the isolation and purification of the deoxyribonucleic acids of Haemophilus pertussis

Determinations by the method of Schmidt \& Thannhauser (1945). Fractions dried with ethanol and ether before analysis.

\begin{tabular}{|c|c|c|c|c|}
\hline \multicolumn{5}{|c|}{ 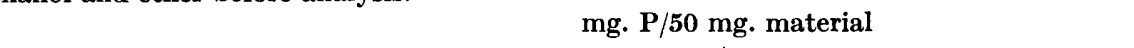 } \\
\hline \multirow[b]{2}{*}{ Material } & \multicolumn{2}{|c|}{ Virulent $H$. pertussis (83E) } & \multicolumn{2}{|c|}{ Avirulent $H$. pertussis $(154 \mathrm{E}$} \\
\hline & $\begin{array}{c}\text { Deoxyribonucleic } \\
\text { acid }\end{array}$ & $\begin{array}{c}\text { Ribonucleic } \\
\text { acid }\end{array}$ & $\begin{array}{c}\text { Deoxyribonucleic } \\
\text { acid }\end{array}$ & $\begin{array}{l}\text { Ribonucleic } \\
\text { acid }\end{array}$ \\
\hline $\begin{array}{l}\text { Cell residue after } \\
\text { extraction with } \\
1 \cdot 0 \mathrm{M} \text { sodium } \\
\text { chloride }\end{array}$ & $0 \cdot 010-0 \cdot 058$ & $0 \cdot 073-0 \cdot 130$ & 0.076 & $0 \cdot 132$ \\
\hline $\begin{array}{l}\text { 'Granular' fraction } \\
(N)\end{array}$ & $0 \cdot 048$ & $0 \cdot 415$ & $\mathbf{0} \cdot \mathbf{0 3 0}$ & $0 \cdot 500$ \\
\hline Nucleoprotein $\left(D_{1}\right)$ & 0.570 & 0.481 & $0 \cdot 485$ & $0 \cdot 471$ \\
\hline Nucleoprotein $\left(D_{3}\right)$ & $0 \cdot 632$ & $\mathbf{0} \cdot 271$ & - & - \\
\hline Nucleoprotein $\left(D_{6}\right)$ & 0.910 & $0 \cdot 195$ & $0 \cdot 820$ & $0 \cdot 210$ \\
\hline $\begin{array}{l}\text { Protein moiety re- } \\
\text { moved from nucleo- } \\
\text { protein by Sevag's } \\
\text { (1934) method }\end{array}$ & $0 \cdot 089$ & $0 \cdot 105$ & $\mathbf{0} \cdot 105$ & $0 \cdot 143$ \\
\hline
\end{tabular}

as described above. This suspension was then diluted with $S_{1}(50 \mathrm{ml}$.) and centrifuged. The supernatant was combined with $S_{2}$ and absolute ethanol (1.5 vol.) added. The fibrous precipitate $\left(D_{1}\right)$, which separated immediately, was rapidly removed from the accompanying granular precipitate $(N)$ by winding around a glass rod. The precipitate $(N)$, which gave a positive biuret and ninhydrin reaction, contained ribonucleic, but little deoxyribonucleic, acid (Table 3 ). The fibrous product $\left(D_{1}\right)$ was transferred to $1.0 \mathrm{M}$ sodium chloride $(300 \mathrm{ml}$.) and stirred until no further material dissolved. The resulting suspension was centrifuged and the insoluble residue extracted for a further $24 \mathrm{hr}$. with $1.0 \mathrm{M}$ sodium chloride $\left(75 \mathrm{ml}\right.$.) at $0^{\circ}$. After centrifuging, this extract was combined with the main solution containing the deoxyribonucleoprotein, and absolute ethanol $\left(1 \cdot 2\right.$ vol.) added. The resulting precipitate of long fibres $\left(D_{2}\right)$ was removed from the granular precipitate as described above. This procedure of alternate solution in $1.0 \mathrm{M}$ sodium chloride and precipitation with ethanol was repeated until the addition of ethanol yielded a fibrous precipitate only. By this method much of the accompanying ribonucleoprotein was removed from the fibrous material (Table 3). This crude deoxyribonucleoprotein, which gave positive biuret, xanthoproteic, Millon, Dische (1930) and Feulgen (1924) reactions, dissolved 
rapidly in water, or in $1.0 \mathrm{~m}$ sodium chloride, to give a viscous solution. It was not, however, precipitated from its solution in $1.0 \mathrm{M}$ sodium chloride on dilution with water and, as recorded above, was soluble in 0.14 $\mathrm{m}$ sodium chloride. In this respect the deoxyribonucleoprotein of $\boldsymbol{H}$. pertussis differs from the deoxyribonucleoproteins of animal tissues (Mirsky \& Pollister, 1942) and from the nucleoprotein isolated by Mirsky \& Pollister (1946) from Type III pneumococci, but resembles the deoxyribonucleoprotein of avian tubercle bacilli (Chargaff \& Saidel, 1949).

\section{Dissociation of the nucleoprotein: isolation of deoxyribonucleic acid}

Prolonged dialysis of a solution of the nucleoprotein in $1.0 \mathrm{~m}$ sodium chloride against $1.0 \mathrm{M}$ sodium chloride at $2^{\circ}$ (cf. Pollister \& Mirsky, 1946), or saturation with sodium chloride (cf. Hammarsten, 1924; Chargaff \& Saidel, 1949) failed to dissociate the nucleoprotein. Accordingly, the protein moiety was removed from the nucleoprotein by the Sevag (1934) method, a procedure which resulted in some loss of deoxyribonucleic acid (Table 3). After eight treatments with chloroform octanol mixture $(9: 1)$ the saline solution was free from protein. Addition of ethanol (4 vol.) resulted in the separation of fibres together with a granular precipitate. The fibrous material was collected and purified by repeated solution in $1.0 \mathrm{M}$ sodium chloride followed by precipitation with ethanol until the final precipitation yielded fibres only. This precipitate was dissolved in distilled water and the solution dialysed for $24 \mathrm{hr}$. at $2^{\circ}$ against frequent changes of distilled water. Finally, the nucleic acid was recovered as white fibres by ethanol precipitation or by evaporation in the frozen state in vacuo.

The nucleic acids thus obtained from both the virulent and avirulent organisms were free from detectable amounts of protein. Furthermore, the analysis of the preparations by the method of Euler \& Hahn (1946) failed to reveal the presence of ribonucleic acid. Owing to the small quantities of nucleic

Table 4. Some properties of the deoxyribonucleic acids of virulent and avirulent strains of Haemophilus pertussis

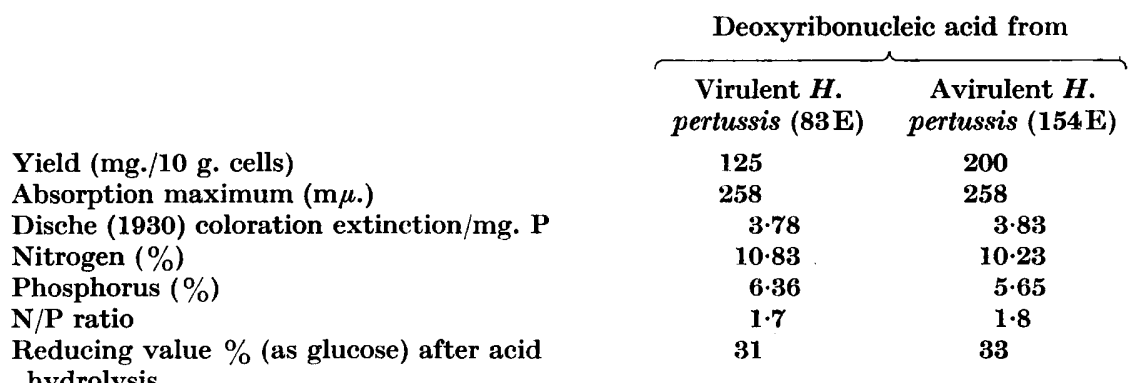

acids available (Table 4), these analyses were restricted to $10 \mathrm{mg}$. quantities. Thus, the presence of traces of protein and ribonucleic acid $(<2 \%)$ in the preparations cannot be excluded. However, the low content of ribonucleic acid 
in the deoxyribonucleic acid preparations, as suggested by these analyses, is of considerable interest when considered in relation to the simple fractionation technique described in this paper, and the difficulties which often attend the separation of mixtures of the nucleic acids (cf. Laland, Overend \& Webb, 1950).

The deoxyribonucleic acid preparations from both the virulent and avirulent organisms contained a polysaccharide component, as indicated by the low analytical figures for nitrogen and phosphorus and by the high reducing values shown after acid hydrolysis (Table 4). The polysaccharide(s) appeared to be firmly bound to the nucleic acids, since the addition of acetic acid or $1 \%(w / v)$ lanthanum acetate to aqueous solutions of the above preparations resulted in the complete precipitation of both polysaccharide and nucleic acid.

Methods for the separation of the carbohydrate component and the immunological examination of the various fractions isolated in the present work are under investigation.

\section{DISCUSSION}

The differences in chemical composition between the virulent and avirulent cells examined will readily be seen from Tables 1 to 4 . Further work is needed to emphasize the significance of these differences, but one particular observation may be of some importance, namely, the fact that the deoxyribonucleic acid is more difficult to extract from the virulent cells. One explanation of this is that it is firmly attached to a polysaccharide which is present in higher proportions possibly at the surface of the virulent cells.

\section{REFERENCES}

Avery, O. T., MacLeod, C. M. \& McCarty, M. (1944). Studies on the chemical nature of the substance inducing transformation of pneumococcal types. Induction of transformation by a desoxyribonucleic acid fraction isolated from pneumococcus type III. J. exp. Med. 79, 137.

Belozerski, A. N. (1947). On the nucleoproteins and polynucleotides of certain bacteria. Cold Spr. Harb. Symp. quant. Biol. $12,1$.

BoIvin, A. (1947). Directed mutation in colon bacilli by an inducing principle of desoxyribonucleic nature; its meaning for the general biochemistry of heredity. Cold Spr. Harb. Symp. quant. Biol. 12, 7.

BoIvin, A. (1948). The two nucleic acids and their function in the constitution and life of bacterial cells. Rev. can. biol. 7, 318.

Boivin, A., Tulasne, R. \& Vendrely, R. (1947). Le rôle des deux acides nucleiques dans la constitution, dans la multiplication, dans la mutation des cellules bactériennes, et plus généralement dans la vie des différentes cellules. Arch. Sci. physiol. 1, 35.

Chargaff, E. \& Saidel, Helen F. (1949). On the nucleoproteins of avian tubercle bacilli. J. biol. Chem. 177, 417 .

Chargaff, E. \& Zamenhof, S. (1947). Highly polymerized desoxypentose nucleic acid from yeast. J. Amer. Chem. Soc. 69, 975.

Chargaff, E. \& Zamenhof, S. (1948). The isolation of highly polymerized desoxypentosenucleic acid from yeast cells. J. biol. Chem. 173, 327.

Cohen, S. M. \& Wheeler, N. W. (1946). Pertussis vaccine prepared with Phase I cultures grown in fluid medium. Amer. J. publ. Hlth, 36, 371.

Dische, Z. (1930). Some new characteristic colour tests for thymonucleic acid and a microchemical method for determining the same in animal organs by means of these tests. Microchemie, 8,4 . 
Hammarsten, E. (1924). The biological significance of nucleic acid compounds. Biochem. Z. 144, 383.

Euler, H. von \& HAHN, L. (1946). A new method for the quantitative determination of ribonucleic acid in animal tissues. Svensk kem. Tidskr. 58, 251.

Feulgen, R. \& Rossenbeck, H. (1924). Microchemical test for nucleic acid of the thymonucleic acid type and the selective staining of cell nuclei in microscopic preparations. Z. physiol Chem. 135, 203.

Henry, H. \& Stacey, M. (1943). Histochemistry of the Gram-staining reaction for micro-organisms. Nature, Lond., 151, 671.

Henry, H. \& Stacey, M. (1946). Histochemistry of the Gram-staining reaction for micro-organisms. Proc. Roy. Soc. B, 133, 391.

Laland, S. G., Overend, W. G. \& Webb, M. (1950). Forthcoming communication.

Levene, P. A. \& Bass, L. W. (1931). Nucleic Acids. New York: Chem. Catalog. Co. Inc.

Meyer, K. \& Hahnel, E. (1946). The estimation of lysozyme by a viscosimetric method. J. biol. Chem. 113, 723 .

Mrrsky, A. E. \& Pollister, A. W. (1942). Nucleoproteins of cell nuclei. Proc. Nat. Acad. Sci., Wash., 28, 344.

Mirsky, A. E. \& Pollister, A. W. (1946). Chromosin, a desoxyribose-nucleoprotein complex of the cell nucleus. J. gen. Physiol. 30, 117.

Pitman, M. (1931). Variation and type specificity in the bacterial species Haemophilus influenzae. J. exp. Med. 53, 471 .

Pollister, A. W. \& Mirsky, A. E. (1946). The nucleoprotein of trout sperm. J. gen. Physiol. 30, 101.

Schmidt, G. \& Thannhauser, S. J. (1945). A method for the determination of desoxyribonucleic acid, ribonucleic acid and phosphoprotein in animal tissue. J. biol. Chem. $161,83$.

SEvaG, M. G. (1934). A new physical-deproteinizing method for the preparation of biologically active substances. Biochem. Z. 273, 419 .

Stacey, M. (1947). Bacterial nucleic acids and nucleoproteins. Symp. Soc. exp. Biol. $1,86$.

Ungar, J. \& Muggleton, P. W. (1949). The relationship of the aluminium phosphate precipitation of organisms of Haemophilus pertussis strains to their other biological properties. J. gen. Microbiol. 3, 353.

Ungar, J., James, A. M., Muggleton, P. W., Pegler, H. F. \& Tomich, E. G. (1950). J. gen. Microbiol. 4, 345.

WEBB, M. (1949). The significance of the Gram complex in micro-organisms. 1st Int. Congr. Biochem. Cambridge. 